\title{
Receptura zaczynu lekkiego do uszczelniania otworów w strefie niskich ciśnień złożowych
}

\section{Formula of lightweight cement slurry for sealing boreholes in the low reservoir pressure zone}

\author{
Marcin Kremieniewski ${ }^{1}$, Anna Pikłowska² \\ ${ }^{1}$ Instytut Nafty i Gazu - Państwowy Instytut Badawczy \\ ${ }^{2}$ AGH Akademia Górniczo-Hutnicza im. St. Staszica, Wydział Wiertnictwa, Nafty i Gazu
}

\begin{abstract}
STRESZCZENIE: W technologii uszczelniania kolumn rur okładzinowych w otworze wiertniczym zachodzi niekiedy potrzeba zastosowania zaczynu o obniżonej gęstości. Najczęściej ma to miejsce w przypadku uszczelniania otworu wierconego w strefie niskiego ciśnienia złożowego. Aby zaprojektować recepturę zaczynu lekkiego, stosuje się dodatek materiału wypełniającego, którego gęstość jest znacznie niższa niż gęstość cementu. Jednak obecność takiego dodatku w strukturze płynnego zaczynu cementowego może niekiedy powodować destabilizację układu objawiającą się nadmiernym frakcjonowaniem, w wyniku czego lekkie cząsteczki migrują w górne partie zaczynu, a ciężkie ziarna cementu opadają na dno. Ponadto zaczyny zawierające dodatki lekkie wykazują również obniżone wartości parametrów mechanicznych, większą porowatość i przepuszczalność dla gazu. Cechy te mogą dyskwalifikować dany zaczyn pod kątem zastosowania go w warunkach otworowych. W celu wyeliminowania tych niekorzystnych zmian zachodzących w strukturze zarówno płynnego, jak i stwardniałego zaczynu lekkiego, stosuje się domieszki pozwalające na znaczną poprawę parametrów technologicznych projektowanej receptury. Odpowiedni dobór zarówno ilościowy, jak i jakościowy wybranych środków umożliwia wyeliminowanie frakcjonowania zaczynu, w wyniku czego możliwe jest uzyskanie homogenicznej struktury płynnego zaczynu, a powstały po związaniu płaszcz cementowy będzie wykazywał izotropię badanych parametrów. Ponadto dodatki i domieszki drobnocząsteczkowe pozwalają doszczelnić matrycę płaszcza cementowego w taki sposób, że wytrzymałość na ściskanie ulega znacznej poprawie i zredukowana zostaje wartość przepuszczalności i porowatości. W artykule zostały omówione wyniki badań nad opracowaniem receptur zaczynów lekkich przeznaczonych do uszczelniania otworów w strefie niskich ciśnień złożowych. Jako próbkę kontrolną przyjęto recepturę, która była stosowana w warunkach otworowych. Zaczyn ten ze względu na brak stabilności sedymentacyjnej został wytypowany do modyfikacji. Kolejne receptury zawierały zróżnicowane ilości materiałów wypełniających. Jako dodatki lekkie użyto: perlit filtracyjny, mikrosferę glinokrzemianową oraz mikrosferę szklaną. Natomiast w celu poprawy stabilności sedymentacyjnej i uzyskania odpowiednich wartości parametrów mechanicznych użyto dwie formy krzemionki: koloidalny roztwór krzemianu sodu oraz nanokrzemionkę hydrofilową. Zaprojektowane receptury zaczynów charakteryzowały się odpowiednimi wartościami parametrów technologicznych i stabilnością sedymentacyjną. Wprowadzone modyfikacje w recepturach zaczynów pozwoliły na osiągnięcie homogenicznej mikrostruktury stwardniałego zaczynu oraz uzyskanie wzrostu wartości parametrów mechanicznych. Opracowana grupa receptur może być stosowana do uszczelniania w strefie niskich ciśnień złożowych w warunkach temperatury około $30^{\circ} \mathrm{C}$ i w ciśnieniu około $3 \mathrm{MPa}$.
\end{abstract}

Słowa kluczowe: zaczyn cementowy, zaczyn lekki, cementowanie otworów wiertniczych, frakcjonowanie, sedymentacja, anizotropia.

\begin{abstract}
In the technology of sealing casing columns in a borehole, sometimes it is necessary to use cement slurry with reduced density. This occurs most often during sealing of the borehole in the low reservoir pressure zone. To design lightweight cement slurry, an addition of filler material is used, the density of which is much lower than the density of cement. However, the presence of such an additive in the structure of fresh cement slurry may sometimes cause destabilization of the system manifested by excessive fractionation, as a result of which light particles migrate to the upper parts of the cement slurry and heavy cement grains sink to the bottom. In addition, cement slurries containing light additives also show reduced values of mechanical parameters, greater porosity and capacity for gas migration, which may disqualify a given cement slurry for use in borehole conditions. In order to eliminate these adverse changes occurring in the structure of both fresh and hardened lightweight cement slurry, admixtures are used to significantly improve the technological parameters of the designed recipe. Appropriate selection, both quantitative and qualitative, of selected agents makes it possible to eliminate the cement slurry fractionation, as a result of which it is possible to obtain a homogeneous structure of the fresh cement slurry, and the cement sheath formed after setting will demonstrate the isotropic properties of the tested mechanical parameters. In addition, additives and low molecular weight admixtures allow sealing of the cement sheath matrix in such a way that the compressive
\end{abstract}

Autor do korespondencji: M. Kremieniewski, e-mail: marcin.kremieniewski@inig.pl

Artykuł nadesłano do Redakcji: 30.04.2020 r. Zatwierdzono do druku: 20.08.2020 r. 
strength is significantly improved and the value of permeability and porosity is reduced. The article discusses the results of research on the development of lightweight cement slurry recipes intended for scaling of openings in the zone of low reservoir pressures. As a control sample, a recipe was selected that had been used in well conditions. This cement slurry was selected for modification due to the lack of sedimentation stability. The following recipes contained various amounts of filling materials. As light additives, filter perlite, aluminosilicate microsphere and glass microsphere were used. However, two forms of silica were used to improve sedimentation stability and obtain appropriate mechanical parameters: a colloidal sodium silicate solution and hydrophilic nanosilica. The designed cement slurry recipes were characterized by appropriate technological parameters and sedimentation stability. The modifications introduced to the cement slurries allowed to achieve a homogeneous microstructure of the hardened cement slurry and an increase in the value of mechanical parameters was obtained. The developed group of recipes can be used to seal openings in the low reservoir pressure zone at a temperature of about $30^{\circ} \mathrm{C}$ and a pressure of about $3 \mathrm{MPa}$.

Key words: cement slurry, lightweight slurry, well cementing, fractionation, sedimentation, anisotropy.

\section{Wprowadzenie}

Wiercenie otworu w strefie niskiego ciśnienia złożowego stanowi jeden z częściej napotykanych problemów. Związane jest to z sypliwością warstw na skutek zaburzeń tektonicznych oraz ze szkodliwym wpływem płuczki na skałę. W pierwszym przypadku skała jest jednolita i pokruszona i w trakcie wiercenia dochodzi do naruszenia stanu równowagi naprężeń, co z kolei jest przyczyną sypania. Tego rodzaju zaburzenia mogą się pojawiać w znacznym interwale wierconego odcinka otworu (Nelson, 1990; Kremieniewski, 2019b; Kremieniewski i Stryczek 2019). Zjawisko takie jest niebezpieczne ze względu na możliwość obsypania i przechwycenia rur płuczkowych i obciążników. Taki stan przedstawiono na rysunku 1. Prędkość wypływu płuczki w takim odcinku otworu o znacznie większej średnicy niż nominalna, ulega obniżeniu, w efekcie czego następuje nieefektywne wynoszenie zwiercin z dna otworu (Brown i Ferg, 2005; Kremieniewski, 2020a). W momencie zatrzymania obiegu cieczy wiertniczej (np. po wyciągnięciu przewodu) może nastąpić sedymentacja zwiercin z płuczki i cała masa skalna przemieści się w dolne partie otworu (Kremieniewski 2017a; Chung et al., 2018; Kremieniewski, 2019c).

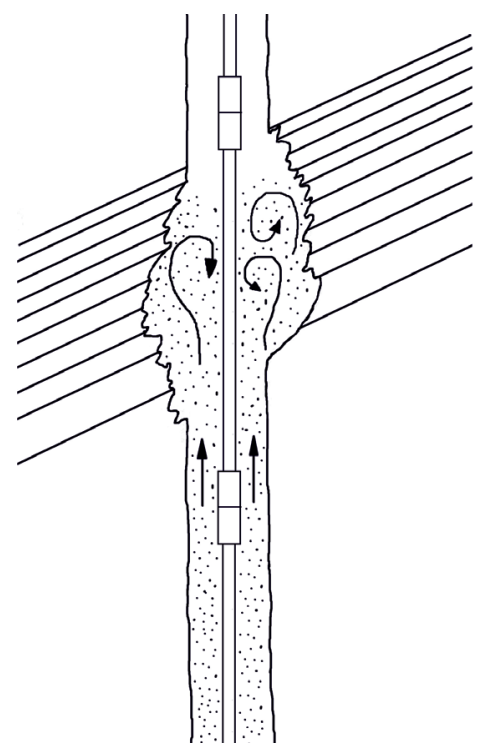

Rys. 1. Tworzenie się zasypu w poszerzonej części otworu w warstwach słabozwięzłych

Fig. 1. The formation of backfill in a wide part of the borehole in low-density layers
Przewiercanie stref o niskich ciśnieniach złożowych oraz stref słabozwięzłych i sypkich może być przyczyną powstawania licznych komplikacji wiertniczych. Środkiem zaradczym dla występowania tego rodzaju problemów na etapie wiercenia jest stosowanie płuczki o odpowiednio dobranych parametrach (Stryczek et al., 2009, 2014; Kremieniewski, 2017b; Abd Elrahman et al., 2019; Kremieniewski 2019d). W celu uszczelniania kolumn rur okładzinowych w takich warunkach geologicznych niezbędne jest zastosowanie zaczynu o obniżonej gęstości, tzw. zaczynu lekkiego, który stosuje się również w następujących przypadkach (Al-Yami et al., 2010; Dohnalik i Zalewska, 2013; Peng i Jacobsen 2013; Kremieniewski, 2018, 2020b; Stryczek et al., 2016):

- podniesienia cementu w przestrzeni pozarurowej na dużą wysokość;

- uszczelnienia otworu, który był wiercony rejonie występowania skał chłonnych;

- uszczelnienia kolumn rur okładzinowych posadowionych w otworze w strefach skał luźnych lub słabozwięzłych przy jednoczesnym wyeliminowaniu zjawiska zaniku zaczynu podczas zabiegu cementowania.

W celu opracowania receptury zaczynu o obniżonej gęstości stosuje się dodatki wypełniające, których gęstość jest znacznie niższa niż gęstość zaczynu. Dodatki takie mają gęstość nasypową od $1300 \mathrm{~kg} / \mathrm{m}^{3}$ do nawet $20 \mathrm{~kg} / \mathrm{m}^{3}$. Tak niskie wartości gęstości dodatków lekkich umożliwiają obniżyć gęstość zaczynu z wartości około $1800 \mathrm{~kg} / \mathrm{m}^{3}$ do wartości około $1000 \mathrm{~kg} / \mathrm{m}^{3}$. Jednak stosowanie lekkich wypełniaczy przysparza pewnego rodzaju problemów, do których można zaliczyć np:
- nadmierne frakcjonowanie zaczynu, kiedy to lekkie frakcje dodatku wypełniającego zawieszone są w górnej części płaszcza cementowego, a frakcje zaczynu, które posiadają większą gęstość opadają w dolne partie otworu (Blanco et al., 2000; Kremieniewski, 2019a). W skrajnych przypadkach obserwować można całkowite rozdzielenie się faz, wewnątrz których może występować niezacementowana przestrzeń wypełniona wodą wydzieloną z zaczynu. Stan taki przedstawiono na rysunku 2; 
- obniżenie wartości parametrów mechanicznych powstałego stwardniałego zaczynu cementowego m.in.: wytrzymałości na ściskanie, wytrzymałości na zginanie, przyczepności do powierzchni rur stalowych i powierzchni formacji skalnej (Daou i Piot, 2008; Kremieniewski et al., 2016);

- wzrost porowatości stwardniałego zaczynu cementowego, co znajduje przełożenie na niższą trwałość płaszcza cementowego i obniżenie wartości wspomnianych parametrów mechanicznych (Stryczek et al., 2005; Sadowski et al., 2017);

- wzrost przepuszczalności dla gazu próbki stwardniałego zaczynu cementowego, który to parametr wynika między innymi ze wzrostu porowatości (Dohnalik i Zalewska, 2013; Jordan et al., 2018; Kremieniewski i Kędzierski, 2020).

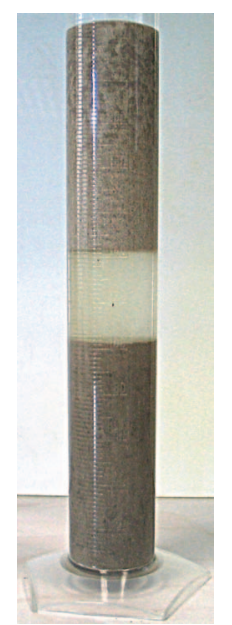

Rys. 2. Nadmierne frakcjonowanie zaczynu zawierającego lekki wypełniacz

Fig. 2. Excessive fractionation of the cement slurry containing light filler

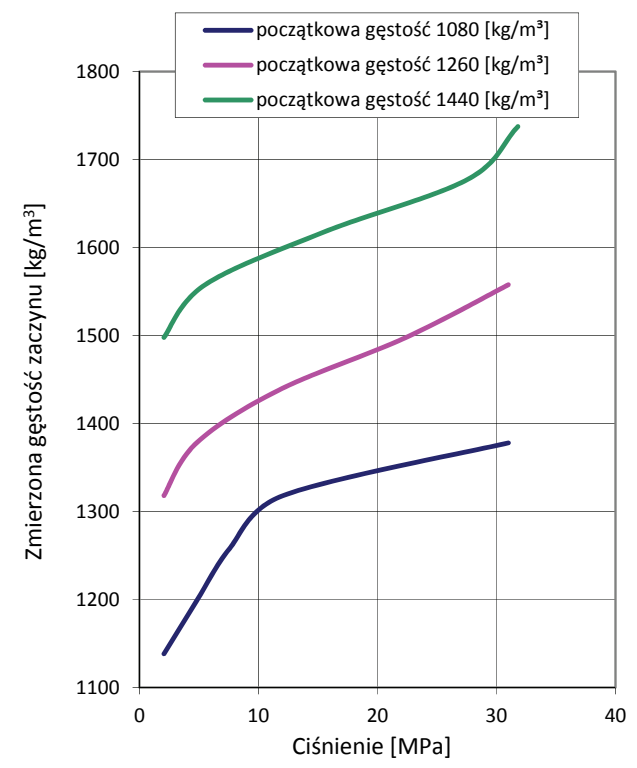

Rys. 3. Wzrost gęstości zaczynów w zależności od ciśnienia

Fig. 3. Increase of cement slurry density depending on pressure

porowatości i przepuszczalności. W dalszej części niniejszej publikacji omówione zostały wyniki badań nad opracowaniem receptury zaczynu lekkiego, który przeznaczony jest do uszczelniania otworów w strefie niskich ciśnień złożowych. Zaprojektowany zaczyn charakteryzuje się wymaganymi wartościami parametrów decydujących o efektywności uszczelniania i może być stosowany w warunkach otworowych.

\section{Przebieg prac badawczych}

Badania nad opracowaniem receptury zaczynu lekkiego do uszczelniania otworów w strefie niskich ciśnień złożowych zostały zrealizowane w Laboratorium Zaczynów Uszczelniających INiG - PIB w oparciu o normy: PN-85/G-02320 Cementy $i$ zaczyny cementowe do cementowania w otworach wiertniczych; PN-EN 10426-2 Przemyst naftowy i gazowniczy. Cementy i materialy do cementowania otworów. Część 2: Badania cementów wiertniczych oraz API SPEC 10 Specification for materials and testing for well cements.

W niniejszej publikacji przedstawione zostały wyniki prac badawczych nad opracowaniem receptur zaczynów lekkich, które można zastosować do uszczelniania otworów w strefie niskich ciśnień złożowych. Do sporządzenia zaczynów zastosowane zostały lekkie materiały wypełniające, których obecność pozwala zmniejszyć wartość gęstości w stosunku do standardowych zaczynów, których gęstość wynosi około $1900 \mathrm{~kg} / \mathrm{m}^{3}$. Podczas projektowania zaczynów użyto również środków, które pomogły poprawić parametry technologiczne zaczynu i powstałego z niego płaszcza cementowego. W zaczynach lekkich znacznym problemem jest wystąpienie frakcjonowania. Takie 
zachowanie skutkuje brakiem stabilności sedymentacyjnej, nadmiernym wydzielaniem wody wolnej z zaczynu. Płaszcz cementowy powstały po związaniu zaczynu charakteryzuje się natomiast anizotropią mikrostruktury. Dlatego też podczas projektowania zaczynu lekkiego najważniejszy jest odpowiedni dobór zarówno jakościowy, jak również ilościowy poszczególnych dodatków i domieszek oraz zastosowanie materiałów przeciwdziałających sedymentacji. Obecność środków przeciwsedymentacyjnych przyczynia się miedzy innymi do wzrostu wartości granicy płynięcia, dzięki czemu zaczyn nie ulega sedymentacji oraz w niewielkim stopniu wykazuje cechy zaczynu tiksotropowego, co jest też korzystne podczas uszczelniania otworów w rejonie występowania niskich wartości ciśnienia złożowego. W trakcie prowadzenia badań nad opracowaniem nowych receptur zaczynów lekkich do uszczelniania otworów w strefie niskich ciśnień złożowych w pierwszej kolejności określono gęstość, stabilność sedymentacyjną oraz odstój wody. Po uzyskaniu wymaganych wartości przystąpiono do pomiaru pozostałych parametrów technologicznych, które decydują o efektywności uszczelniania. Są to parametry reologiczne zaczynu, filtracja zaczynu w warunkach dynamicznych oraz czas gęstnienia w warunkach otworopodobnych. W tabeli 1 przedstawiono składy receptur zaczynów, natomiast w tabeli 2 - uzyskane parametry technologiczne zaczynów. W publikacji zamieszczono tylko pozytywne rezultaty uzyskanych prac badawczych.

Składy zaczynów przeznaczone do uszczelniania otworów w strefie niskich ciśnień złożowych zestawiono w tabeli 1. Zaczyn nr 1 to receptura kontrolna. Jest to skład, który był stosowany podczas zabiegu cementowania otworu GH2. Zaczyn ten sporządzono na osnowie innego rodzaju środków (DS) niż środki użyte podczas projektowania kolejnych receptur. W zaczynie nr 2 do obniżenia gęstości zastosowano mikrosferę glinokrzemianową, w zaczynie nr 3 użyto perlit filtracyjny, zaczyn nr 4 zawiera dodatkowo mikrosferę szklaną, natomiast zaczyn nr 5 to modyfikacja receptury nr 2, która zawiera krzemionkę w formie koloidalnego roztworu krzemianu sodu oraz w postaci nanokrzemionki. Wszystkie receptury sporządzono dla warunków otworowych o temperaturze około $30^{\circ} \mathrm{C}$ i ciśnieniu około $3 \mathrm{MPa}$.

Receptura kontrolna nr 1 to zaczyn o zawartości 25\% mikrosfer glinokrzemianowych. W celu doszczelnienia matrycy cementowej zastosowano 20\% mikrocementu. Współczynnik wodno-cementowy ${ }^{1}$ zaczynu wynosił 0,85 . Tak sporządzony zaczyn posiadał gęstość $1360 \mathrm{~kg} / \mathrm{m}^{3}$ i wykazywał $0,2 \%$ odstoju wody. W zaczynie zaobserwowano brak stabilności sedymentacyjnej i podczas pomiaru gęstości w trzech punktach pomiarowych kolumny sedymentacyjnej uzyskano wartość $1350 \mathrm{~kg} / \mathrm{m}^{3}$ w części górnej, $1360 \mathrm{~kg} / \mathrm{m}^{3}$ w części środkowej oraz 1370 kg/m³ w dolnej. Frakcjonowanie zaczynu mogło być wynikiem niskich wartości parametrów reologicznych zaczynu, którego krzywa płynięcia posiadała najniższy przebieg z grupy analizowanych zaczynów (rys. 4). Granica płynięcia zaczynu wynosiła 5,76 Pa, a jego filtracja w warunkach dynamicznych była równa $92 \mathrm{~cm}^{3} / 30 \mathrm{~min}$. Uzyskane wyniki badań zestawiono w tabeli 2 .

W zaczynie nr 2 zastosowano 40\%-ową ilość mikrosfer. Zwiększono współczynnik wodno-cementowy do wartości 1,

\footnotetext{
${ }^{1}$ Współczynnik wodno-cementowy - ilość wody w zaczynie w stosunku do ilości cementu
}

Tabela 1. Składy wytypowanych zaczynów dla warunków otworowych o temperaturze około $30^{\circ} \mathrm{C}$ i ciśnieniu około $3 \mathrm{MPa}$

Table 1. Compositions of selected slurries for borehole conditions with a temperature of approx. $30^{\circ} \mathrm{C}$ and a pressure of about $3 \mathrm{MPa}$

\begin{tabular}{|c|c|c|c|c|c|}
\hline Sklad & $\begin{array}{c}\text { Zaczyn 1 } \\
\text { kontrolny }\end{array}$ & Zaczyn 2 & Zaczyn 3 & Zaczyn 4 & Zaczyn 5 \\
\hline \hline Woda wodociągowa & 0,85 & 1,0 & 1,0 & 0,85 & 0,8 \\
\hline Bentonit (bwow) & $1,0 \%$ & $2,0 \%$ & $1,0 \%$ & $1,0 \%$ & - \\
\hline Środek odpieniający & $1,0 \%{ }^{*}$ & $0,5 \%$ & $0,5 \%$ & $0,5 \%$ & $0,5 \%$ \\
\hline Środek upłynniający & $0,3 \%^{*}$ & $0,3 \%$ & $0,3 \%$ & $0,3 \%$ & $0,3 \%$ \\
\hline Środek antyfiltracyjny & $0,5 \%^{*}$ & $0,4 \%$ & $0,4 \%$ & $0,4 \%$ & $0,4 \%$ \\
\hline CaCl $_{2}$ & $1,0 \%$ & $3,0 \%$ & $3,0 \%$ & $4,0 \%$ & $4,0 \%$ \\
\hline Mikrosfera glinokrzemianowa & $25,0 \%$ & $40,0 \%$ & - & - & $40,0 \%$ \\
\hline Mikrosfera szklana HS5 & - & - & - & $10,0 \%$ & - \\
\hline Koloidalny roztwór krzemianu sodu CB75 & - & - & - & $0,5 \%$ & $3,0 \%$ \\
\hline Nano SiO & - & - & - & $1,0 \%$ \\
\hline Perlit filtracyjny & - & - & $12,0 \%$ & $10,0 \%$ & - \\
\hline Mikrocement & $20,0 \%$ & - & - & $100,0 \%$ & 100,0 \\
\hline Cement CEM G & $100,0 \%$ & $100,0 \%$ & $100,0 \%$ & 100,0 \\
\hline
\end{tabular}

“Zastosowano inny rodzaj środków (DS) 
Tabela 2. Parametry badanych receptur zaczynów dla warunków otworowych o temperaturze około $30^{\circ} \mathrm{C}$ i ciśnieniu około $3 \mathrm{MPa}$

Table 2. Parameters of the tested slurries for borehole conditions with a temperature of approx. $30^{\circ} \mathrm{C}$ and a pressure of about $3 \mathrm{MPa}$

\begin{tabular}{|c|c|c|c|c|c|c|}
\hline \multicolumn{2}{|l|}{ Parametr } & $\begin{array}{l}\text { Zaczyn } 1 \\
\text { kontrolny }\end{array}$ & Zaczyn 2 & Zaczyn 3 & Zaczyn 4 & Zaczyn 5 \\
\hline \multicolumn{2}{|l|}{ Gęstość $\left[\mathrm{kg} / \mathrm{m}^{3}\right]$} & 1360 & 1260 & 1400 & 1310 & 1300 \\
\hline \multicolumn{2}{|l|}{ Odstój wody [\%] } & 0,2 & 0,0 & 0,0 & 0,0 & 0,0 \\
\hline \multicolumn{2}{|l|}{ Filtracja $\left[\mathrm{cm}^{3} / 30 \mathrm{~min}\right]$} & 92 & 214 & 99 & 175 & 88 \\
\hline \multicolumn{2}{|c|}{ Lepkość plastyczna $[\mathrm{mPa} \cdot \mathrm{s}]$} & 108,0 & 58,5 & 120 & 96,0 & 160 \\
\hline \multicolumn{2}{|c|}{ Granica płynięcia [Pa] } & 5,76 & 30,0 & 13,9 & 29,3 & 11,7 \\
\hline \multirow{3}{*}{$\begin{array}{c}\text { Stabilność sedymentacyjna } \\
\text { Gęstość w części kolumny }\left[\mathrm{kg} / \mathrm{m}^{3}\right]\end{array}$} & Góra & 1350 & 1260 & 1400 & 1360 & 1300 \\
\hline & Środek & 1360 & 1260 & 1400 & 1360 & 1300 \\
\hline & Dół & 1370 & 1260 & 1400 & 1360 & 1300 \\
\hline \multirow{2}{*}{$\begin{array}{l}\text { Czas gęstnienia [godz:min] } \\
\left(\mathrm{t}=30^{\circ} \mathrm{C}^{*}, \mathrm{p}=3 \mathrm{MPa}\right)\end{array}$} & $30 \mathrm{Bc}$ & $4: 45$ & $4: 35$ & $5: 14$ & $4: 25$ & $3: 30$ \\
\hline & $100 \mathrm{Bc}$ & $5: 50$ & $5: 15$ & $5: 50$ & $5: 05$ & $4: 35$ \\
\hline
\end{tabular}

${ }^{*}$ Czas dojścia do temperatury w 10 minut

oraz nie użyto mikrocementu. Poprzez wprowadzenie większej ilości chlorku wapnia oraz bentonitu (tabela 1) uzyskano taki wzrost parametrów reologicznych, który pozwolił na utrzymanie lekkiej frakcji mikrosfer w całej objętości zaczynu. Tego rodzaju działania miały na celu wychwycenie możliwości poprawy stabilności sedymentacyjnej za pomocą domieszki chlorku wapnia i jednocześnie zwiększenia ilości wody w zaczynie. Zastosowano również innego rodzaju środek odpieniający, upłynniający i antyfiltracyjny. Po wprowadzeniu takiego rodzaju modyfikacji zaczyn posiadał znacznie niższą gęstość $\left(1260 \mathrm{~kg} / \mathrm{m}^{3}\right)$ niż zaczyn kontrolny. Korzystnym czynnikiem jest brak frakcjonowania. Zaczyn posiadał takie same wartości gęstości we wszystkich punktach pomiaru, pomimo większej (niż w zaczynie kontrolnym) zawartości zarówno wody, jak i mikrosfer glinokrzemianowych. Dodatkowo zaczyn nie wykazywał również odstoju wody (tabela 2), co jest efektem podwyższonych wartości parametrów reologicznych, gdzie krzywa płynięcia (rys. 4) posiada wysokie wartości naprężeń stycznych przy średnich wartościach szybkości ścinania. Granica płynięcia zaczynu wynosiła $30 \mathrm{~Pa}$. Ze względu na dużą zawartość mikrosfer, filtracja zaczynu była wyższa niż w recepturze kontrolnej i wynosiła $214 \mathrm{~cm}^{3} / 30 \mathrm{~min}$.

W trzecim zaczynie do obniżenia gęstości zastosowano dodatek $12 \%$ perlitu filtracyjnego, współczynnik wodno-cementowy wynosił $1 \mathrm{i}$ zastosowano $1 \%$ bentonitu. Użycie perlitu o wysoko rozwiniętej powierzchni właściwej pozwoliło na uzyskanie gęstości równej $1400 \mathrm{~kg} / \mathrm{m}^{3}$. Filtracja zaczynu została zredukowana do wartości $99 \mathrm{~cm}^{3} / 30 \mathrm{~min}$. Zaczyn nie wykazywał odstoju wody i był stabilny sedymentacyjnie, mimo niewielkiej wartości granicy płynięcia równiej 13,9 Pa (tabela 2) oraz niskiego przebiegu krzywej płynięcia na rysunku 4. Taka kompozycja zaczynu może być ekonomiczną alternatywą dla pozostałych receptur ze względu na niewielki udział składników.

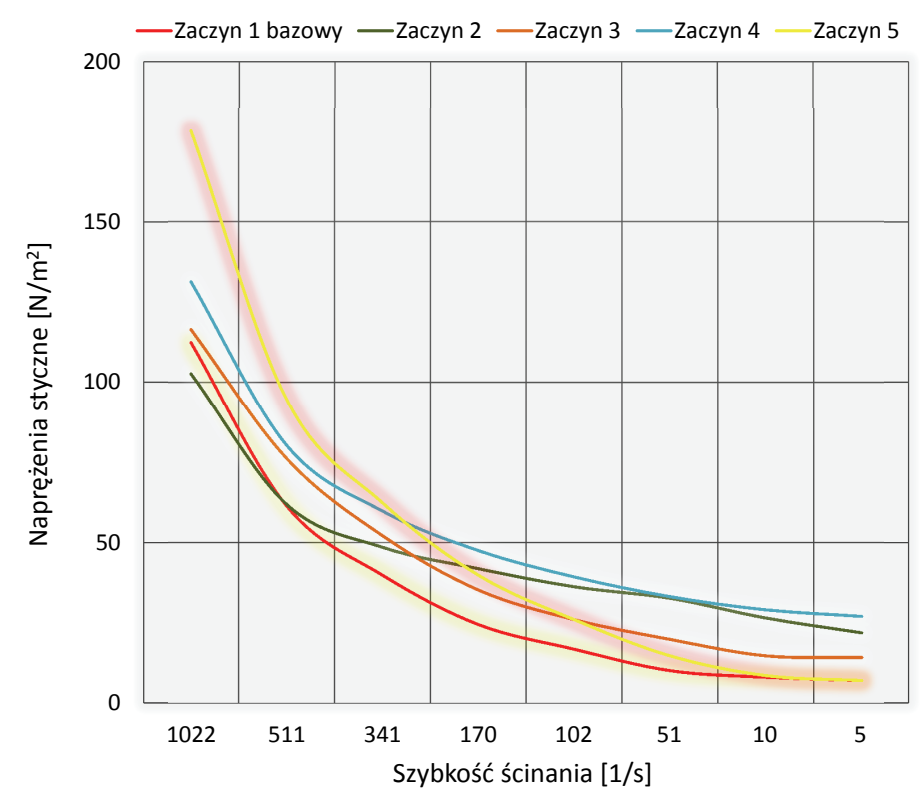

Rys. 4. Przebieg wartości krzywych płynięcia omawianych receptur zaczynów cementowych

Fig. 4. The course of values of the flow curves of the discussed cement slurries

Zaczyn $\mathrm{nr} 4$ to receptura, która również zawiera perlit filtracyjny, jednak w ilości 10\%. Z uwagi na mocne zagęszczanie zaczynu domieszką perlitu, nie zwiększano jego ilości tylko wprowadzono dodatkowo $10 \%$ mikrosfery szklanej HS5. Do poprawy stabilności zaczynu zastosowano koloidalny roztwór krzemianu sodu w ilości $0,5 \%$. Tak sporządzony zaczyn posiadał gęstość $1310 \mathrm{~kg} / \mathrm{m}^{3}$, a jego filtracja wynosiła $175 \mathrm{~cm}^{3} / 30 \mathrm{~min}$. Zaczyn był stabilny sedymentacyjnie i nie wykazywał odstoju wody. Granica płynięcia zaczynu była najwyższa z zestawionych receptur (tabela 2) i wynosiła 29,3 Pa, a wartości naprężeń stycznych były najwyższe dla średnich szybkości ścinania, co przedstawia rysunek 4. 
Piąty zaczyn zawiera podobnie jak receptura $\mathrm{nr} 2,40 \% \mathrm{mi}-$ krosfer glinokrzemianowych, jednak w zaczynie tym zmniejszono ilość wody do 0,8 i nie zastosowano domieszki bentonitu. Najbardziej istotną różnicą było wprowadzenie 3\% koloidalnego roztworu krzemianu sodu, który pełni funkcję stabilizatora i dodatkowo do zaczynu dodano $1 \%$ nanokrzemionki. Jej prowadzenie wynikało z synergii w działaniu tych dwóch komponentów - koloidalnego roztworu krzemianu sodu oraz nanokrzemionki hydrofilowej. Tak sporządzony zaczyn miał gęstość $1300 \mathrm{~kg} / \mathrm{m}^{3}$, nie posiadał odstoju wody, a wartość filtracji była najniższa $\left(88 \mathrm{~cm}^{3} / 30 \mathrm{~min}\right) \mathrm{z}$ grupy badanych zaczynów przedstawionych w tabeli 2. Granica płynięcia zaczynu wynosiła 11,7 Pa, a krzywa płynięcia (rys. 4) miała najwyższy przebieg jedynie przy maksymalnych szybkościach ścinania.

Analizując uzyskane wyniki wartości parametrów mechanicznych (rys. 5) zaobserwowano, że stwardniały zaczyn cementowy z próbki kontrolnej (nr 1) posiadał najniższe wartości wytrzymałości na ściskanie. Uzyskano wartości od 4,8 MPa po 2 dniach hydratacji do $8,1 \mathrm{MPa}$ po 28 dniach hydratacji. Zaczyn nr 2 posiadał nieznacznie wyższe wartości wytrzymałości pomimo wprowadzenia większej (40\%-owej) ilości mikrosfer. Takie zachowanie może być związane $\mathrm{z}$ obecnością $3 \% \mathrm{CaCl}_{2}$ w zaczynie $\mathrm{nr} 2$, przez co hydratacja zaczynu następowała w bardziej dynamiczny sposób. Kolejny wzrost wytrzymałości (rys. 5) widoczny był dla zaczynu nr 3, w którym zamiast mikrosfer glinokrzemianowych zastosowano dodatek perlitu pylistego. Jednak wyższe wartości wytrzymałości wynikają z mniejszej zdolności perlitu do obniżania gęstości zaczynu. Zaczyn nr 3 posiadał najwyższą gęstość $\mathrm{z}$ analizowanej grupy zaczynów zestawionych w tabeli 2 . W celu utrzymania parametrów podwyższonych wartości parametrów mechanicznych do kolejnej receptury oznaczonej nr 4 wprowadzono oprócz perlitu dodatkowo mikrosferę szklaną i koloidalny roztwór krzemianu sodu. Takie działanie okazało się słuszne, ponieważ uzyskano przyrost wartości wytrzymałości w zakresie od 8,1 MPa po 2 dniach hydratacji do 12,8 MPa po 28 dniach hydratacji przy jednoczesnym obniżeniu gęstości w porównaniu do zaczynu $\mathrm{nr} 3$. Zaobserwowano również, że zaczyn z domieszką koloidalnego roztworu krzemianu sodu posiadał najwyższą z badanych próbek wartość wczesnej wytrzymałości na ściskanie po 2 dniach hydratacji (rys. 5). Zaczyn oznaczony nr 5 posiadał najwyższe wartości wytrzymałości na ściskanie po czasie od 7 do 28 dni hydratacji (rys. 5). Pomimo obecności w zaczynie 40\% mikrosfer glinokrzemianowych, uzyskano mocny przyrost wytrzymałości mechanicznej poprzez zmniejszenie współczynnika wodno cementowego i wprowadzenie domieszki 3\% koloidalnego roztworu krzemianu sodu oraz 1\% nanokrzemionki. Jednoczesna obecność tych dwóch środków skutkuje działaniem synergicznym, co przekłada się na przyrost wartości parametrów mechanicznych.

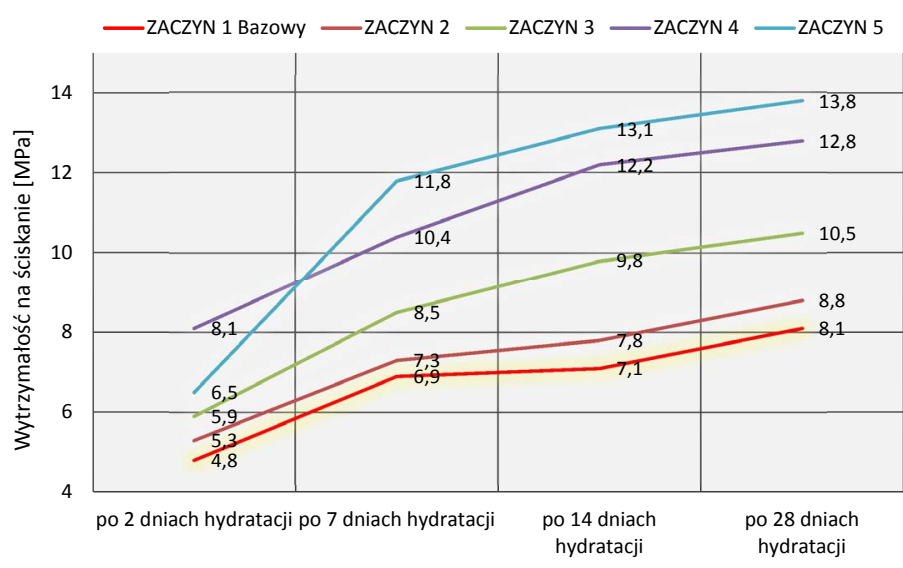

Rys. 5. Porównanie uzyskanych wartości wytrzymałości na ściskanie Fig. 5. Comparison of obtained compressive strength values

Dla próbek stwardniałych zaczynów cementowych wykonane zostały również badania anizotropii struktury. $\mathrm{W}$ tym celu płynny zaczyn umieszczono w szklanej rurce o średnicy $2,5 \mathrm{~cm}$ i długości $50 \mathrm{~cm}$. Po okresie hydratacji 28 dni wykonano badania porowatości z górnej, środkowej i dolnej części cylindra. Na podstawie różnicy w uzyskanych wartościach porowatości stwierdzono jednorodność w mikrostrukturze próbki. Na podstawie uzyskanych wyników badań porowatości (rys. 6) zaobserwowano największą różnicę jedynie w próbce kontrolnej oznaczonej nr 1. Próbka posiadała porowatość 51,78\% w górnej części oraz 50,67\% w części dolnej. Takie różnice potwierdzają destabilizację układu płynnego zaczynu, efektem czego jest tworzenie się anizotropowej mikrostruktury płaszcza cementowego w otworze wiertniczym. Pozostałe próbki posiadały porównywalne wartości porowatości. Ewentualne różnice zawierały się w zakresie setnych części procenta.

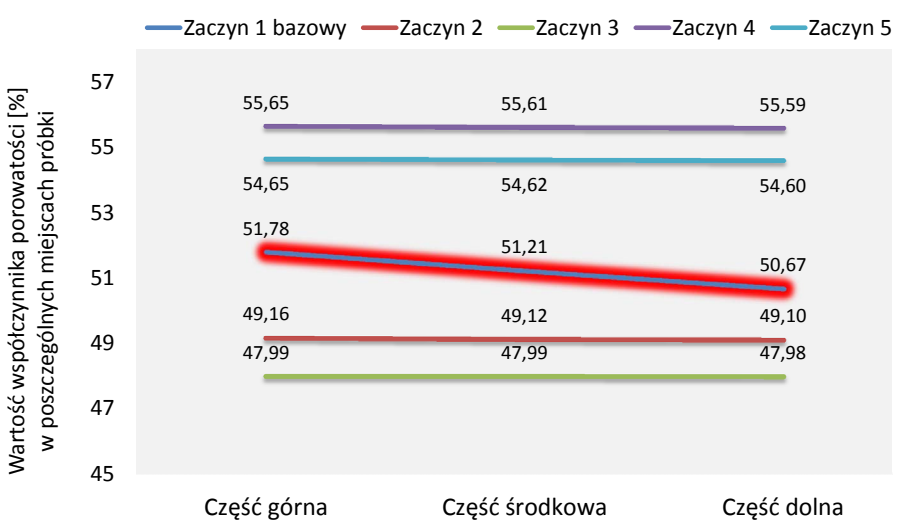

Rys. 6. Zestawienie wartości porowatości stwardniałego zaczynu w zależności od miejsca poboru próbki (izotropia struktury)

Fig. 6. Comparison of porosity values depending on the sampling point (structure isotropy)

Na podstawie uzyskanych wyników badań mikrostruktur próbek stwardniałych zaczynów przeprowadzono również analizę procentowego udziału porów należących do określonego 
zakresu średnic. W celu ograniczenie przepuszczalności dla gazu przez strukturę płaszcza cementowego wymagane jest uzyskanie jak największego udziału przestrzeni porowych o najmniejszych średnicach oraz minimalnego udziału porów o dużych średnicach. Analizując przedstawiony na rysunku 7 procentowy udział porów dla poszczególnych próbek stwierdzono, że największy udział przestrzeni porowych o największych średnicach (kolor czerwony) posiada próbka z zaczynu kontrolnego $\mathrm{nr}$ 1. Natomiast najmniejszy udział dużych przestrzeni porowych posiada próbka zawierająca domieszkę nanokrzemionki i koloidalnego roztworu krzemianu sodu. Zielonym kolorem zaznaczono udział procentowy porów najmniejszych w zakresie od 0,05 mikrometra do 0,01 mikrometra. Takich porów, które nie biorą udziału w przepuszczalności stwardniałego zaczynu cementowego najwięcej zaobserwowano w próbce $\mathrm{nr} 5$ i na tej podstawie można stwierdzić, że charakteryzować się ona będzie najniższym współczynnikiem przepuszczalności dla gazu.

\begin{tabular}{|c|c|c|c|c|}
\hline \multirow[b]{2}{*}{ Próbka 5} & \multicolumn{2}{|c|}{$\begin{array}{l}\text { udział porów }>1 \mu \mathrm{m} \\
\text { udział porów od } 0,1 \text { do } 0,05 \mu \mathrm{m}\end{array}$} & \multicolumn{2}{|c|}{$\begin{array}{l}\text { ⿴udział porów od } 1,0 \text { do } 0,1 \mu \mathrm{m} \\
\text { घudział porów od } 0,05 \text { do } 0,01 \mu \mathrm{m}\end{array}$} \\
\hline & 4,6571 & 41,323 & 20,9863 & 33,0336 \\
\hline Próbka 4 & 4,6151 & 41,4183 & 21,5837 & 32,3829 \\
\hline Próbka 3 & 5,8993 & 45,59 & 20,9176 & 26,5931 \\
\hline Próbka 2 & 5,4592 & 45,1817 & 21,2119 & 27,1473 \\
\hline $\begin{array}{l}\text { Próbka } 1 \\
\text { bazowa }\end{array}$ & 3,4592 & 47,1817 & 21,2119 & 23,1473 \\
\hline & & 40 & 60 & 80 \\
\hline
\end{tabular}

Rys. 7. Procentowy udział porów o określonym zakresie średnic

Fig. 7. Percentage of pores with a specific diameter range

\section{Wnioski}

Na podstawie zrealizowanych prac badawczych sformułowano następujące wnioski końcowe:

1. Zaczyn kontrolny ulegał frakcjonowaniu, co jest wynikiem najniższego przebiegu krzywej płynięcia, dlatego też stwierdza się, że stabilność sedymentacyjna zależy od parametrów reologicznych, a najbardziej od wartości granicy płynięcia zaczynu.

2. Zastosowanie chlorku wapnia w zaczynie cementowym skutkuje wzrostem parametrów reologicznych, co przekłada się na poprawę stabilności sedymentacyjnej zaczynu.

3. Zastosowanie perlitu filtracyjnego do obniżania gęstości zaczynu to ekonomiczna alternatywa dla mikrosfer glinokrzemianowych, ponieważ zaczyn przy niewielkiej ilości składników posiada bardzo dobre parametry technologiczne, które pozwalają na zastosowanie go w warunkach otworowych. Zaczyn z dodatkiem perlitu nie frakcjonuje, ma niską wartość filtracji, a struktura stwardniałego zaczynu wykazuje homogeniczność.

4. Wprowadzenie do zaczynu domieszki perlitu i mikrosfery szklanej skutkuje mocnym obniżeniem gęstości oraz powoduje poprawę parametrów mechanicznych przy jednoczesnym obniżeniu kosztów w porównaniu do zaczynu zawierającego tylko mikrosferę szklaną.

5. Obecność 3\% koncentracji chlorku wapnia w zaczynie cementowym powoduje wzrost wytrzymałości na ściskanie w porównaniu do próbki kontrolnej.

6. Wprowadzenie koloidalnego roztworu krzemianu sodu do receptury zaczynu powoduje poprawę parametrów mechanicznych głównie w początkowym okresie hydratacji (do 48 godzin).

7. Zaczyn cementowy nieposiadający stabilności sedymentacyjnej tworzył anizotropową mikrostrukturę płaszcza cementowego.

8. Doszczelnienie matrycy cementowej za pomocą nanokrzemionki i koloidalnego roztworu krzemianu sodu powoduje skuteczne wypełnienie mikrostruktury międzyziarnowej. W wyniku takiego działania uzyskano znaczny wzrost udziału porów o najmniejszej średnicy, które nie biorą udziału w przepuszczalności gazu.

9. Uzyskane wartości parametrów technologicznych opracowanej grupy zaczynów z wytypowanymi domieszkami pozwalają na zastosowanie ich podczas uszczelniania otworów wiertniczych w strefie niskich ciśnień złożowych w zakresie warunków o temperaturze ok. $30^{\circ} \mathrm{C}$ i ciśnienia ok. $3 \mathrm{MPa}$.

Artykuł powstał na podstawie prac pt.: Analiza możliwości poprawy parametrów technologicznych zaczynu cementowego za pomoca domieszki grafenu - praca INiG - PIB na zlecenie MNiSW; nr zlecenia: 0024/KW/2020, nr archiwalny: DK-4100/0024/2020 oraz wybranych wyników podczas realizacji pracy doktorskiej pt.: Wpływ nanoczastek krzemionki na zmianę parametrów świezego i stwardniatego zaczynu cementowego w aspekcie poprawy skuteczności uszczelniania kolumny rur okładzinowych w głębokich otworach wiertniczych (autor: mgr inż. Anna Pikłowska).

\section{Literatura}

Abd Elrahman M., Chung S.Y., Sikora P., Rucinska T., Stephan D., 2019. Influence of nanosilica on mechanical properties, sorptivity, and microstructure of lightweight concrete. Materials, 12(19): 3078. DOI: 10.3390/ma12193078.

Al-Yami A.S., Nasr-El-Din H.A., Al-Humaidi A.S., Al-Saleh S.H., Al-Arfaj M.K., 2010. Evaluation and Optimization of Low-Density Cement: Laboratory Studies and Field Application. Society of Petroleum Engineers. DOI: 10.2118/113090-PA.

Blanco F., García P., Mateos P., Ayala J., 2000. Characteristics 
and properties of lightweight concrete manufactured with cenospheres. Cem. Concr. Res., 30: 1715-1722. DOI: 10.1016/ S0008-8846(00)00357-4.

Brown D.L., Ferg T.E., 2005. The Use of Lightweight Cement Slurries and Downhole Chokes on Air-Drilled Wells. Society of Petroleum Engineers. DOI: 10.2118/84561-PA.

Chung S.-Y., Abd Elrahman M., Stephan D., Kamm P.H., 2018. The influence of different concrete additions on the properties of lightweight concrete evaluated using experimental and numerical approaches. Constr. Build. Mater., 189, 314-322. DOI: 10.1016/j. conbuildmat.2018.08.189.

Daou F., Piot B.M., 2008. Cement-Slurry Performance and Set-Cement Properties vs. Microsilica Densification. Society of Petroleum Engineers. DOI: 10.2118/112701-PA.

Dohnalik M., Zalewska J., 2013. Korelacja wyników laboratoryjnych uzyskanych metodą rentgenowskiej mikrotomografii, jądrowego rezonansu magnetycznego i porozymetrii rtęciowej. Nafta-Gaz, 10: 735-743.

Jordan A., Pernites R., Albrighton L., 2018. Low-density, lightweight cement tested as alternative to reduce lost circulation, achieve desired top of cement in long horizontal wells. Drilling Contractor, September/October: 62-64.

Kremieniewski M., 2017a. Poprawa stabilności sedymentacyjnej zaczynu cementowego. Nafta-Gaz, 4: 242-249. DOI: 10.18668/ NG.2017.04.04.

Kremieniewski M., 2017b. Wpływ perlitu pylistego na własności technologiczne zaczynu cementowego. Nafta-Gaz, 12: 943-952 DOI 10.18668/NG.2017.12.05.

Kremieniewski M., 2018. Poprawa wczesnej wytrzymałości mechanicznej płaszcza cementowego powstałego z zaczynu lekkiego. Nafta-Gaz, 8: 599-605. DOI: 10.18668/NG.2018.08.06.

Kremieniewski M., 2019a. Korelacja wyników badań filtracji i wczesnej wytrzymałości mechanicznej zaczynów cementowych z dodatkiem mączki krzemionkowej. Nafta-Gaz, 7: 394-403. DOI: 10.18668/NG.2019.07.03.

Kremieniewski M., 2019b. Receptury zaczynów do uszczelniania kolumn rur posadowionych w otworach wierconych w skałach chłonnych. Nafta-Gaz, 8: 451-457. DOI: 10.18668/NG.2019.08.01.

Kremieniewski M., 2019c. Rola plastyfikatora w projektowaniu zaczynu lekkiego o podwyższonej stabilności sedymentacyjnej. Nafta-Gaz, 9: 571-578. DOI: 10.18668/NG.2019.09.06.

Kremieniewski M., 2019d. Wpływ drobnoziarnistej krzemionki na parametr czasu oczekiwania na cement - WOC. Nafta-Gaz, 11: 683-690. DOI: 10.18668/NG.2019.

Kremieniewski M., 2020a. Recipe of Lightweight Slurry with High Early Strength of the Resultant Cement Sheath. Energies, 1583: 1-13. DOI: $10.3390 /$ en 13071583.

Kremieniewski M., 2020b. Zaczyny do uszczelniania otworów w warunkach niskich wartości gradientów ciśnienia szczelinowania skał oraz do prac rekonstrukcyjnych. Nafta-Gaz, 2: 102-109, DOI: $10.18668 /$ NG.2020.02.04.

Kremieniewski M., Kędzierski M., 2020. Wpływ wybranych domieszek obniżających gęstość na parametry zaczynu cementowego. Nafta-Gaz, 3: 143-153. DOI: 10.18668/NG.2020.03.01.

Kremieniewski M., Stryczek S., 2019. Zastosowanie cementu wysokoglinowego do sporządzania zaczynów uszczelniających w technologiach wiertniczych. Cement Wapno Beton, 22/84(3): 215-226.
Kremieniewski M., Stryczek S., Wiśniowski R., Gonet A., 2016. Zmniejszanie porowatości stwardniałych zaczynów wiertniczych poprzez wprowadzenie dodatków drobnoziarnistych. Cement Wapno Beton, 21/83(5): 325-335.

Nelson E.B., 1990. Well Cementing. Schlumberger Educational Service, Houston, Teksas, USA.

Peng Ya, Jacobsen S., 2013. Influence of water/cement ratio, admixtures and filler on sedimentation and bleeding of cement paste. Cement and Concrete Research, 54: 133-142. DOI: 10.1016/j. cemconres.2013.09.003.

Sadowski Ł., Popek M., Czarnecki S., Mathia T.G., 2017 Morphogenesis in solidification phases of lightweight concrete surface at early ages. Constr. Build. Mater., 148: 96-103. DOI: 10.1016/j.conbuildmat.2017.05.026.

Shabbar R., Nedwell P., Wu Z., 2017. Mechanical properties of lightweight aerated concrete with different aluminum powder content. MATEC Web of Conf., 120: 02010. DOI: 10.1051/matecconf $/ 201712002010$.

Stryczek S., Gonet A., Wiśniowski R., 2005. Wpływ wybranego dodatku mineralnego na własności technologiczne zaczynów cementowych. Wiertnictwo, Nafta, Gaz, 22(1): 333-341.

Stryczek S., Wiśniowski R., Gonet A., Ferens W., 2009. Parametry reologiczne świeżych zaczynów uszczelniających w zależności od czasu ich sporządzania. Wiertnictwo, Nafta, Gaz, 26(1-2): 369-382.

Stryczek S., Wiśniowski R., Gonet A., Złotkowski A., 2014 The influence of time of rheological parameters of fresh cement slurries. AGH Drilling, Oil, Gas, 31: 123-133. DOI 10.7494/ drill.2014.31.1.123.

Stryczek S. (red.), Wiśniowski R., Uliasz-Misiak B., Złotkowski A., Kotwica Ł., Rzepka M., Kremieniewski M., 2016. Studia nad doborem zaczynów uszczelniających w warunkach wierceń w basenie pomorskim. Wydawnictwo AHG, Kraków.

Wiśniowski R., Stryczek S., Skrzypaszek K., 2007. Kierunki rozwoju badań nad reologią płynów wiertniczych. Wiertnictwo, Nafta, Gaz, 24: 595-607.

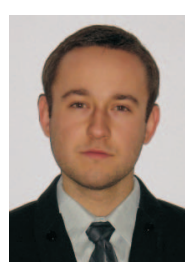

Dr inż. Marcin KREMIENIEWSKI

Adiunkt w Zakładzie Technologii Wiercenia Instytut Nafty i Gazu - Państwowy Instytut Badawczy ul. Lubicz 25 A 31-503 Kraków

E-mail:marcin.kremieniewski@inig.pl

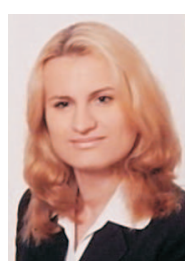

Mgr inż. Anna PIKŁOWSKA

Doktorant w Katedrze Wiertnictwa i Geoinżynierii Akademia Górniczo-Hutnicza im. St. Staszica Wydział Wiertnictwa, Nafty i Gazu al. Mickiewicza 30 30-059 Kraków E-mail:apiklow@agh.edu.pl 